IBIMA Publishing

Journal of Innovation \& Business Best Practice

https://ibimapublishing.com/articles/JIBBP/2021/707843/

Vol. 2021 (2021), Article ID 707843, 16 pages, ISSN: 2166-0743

DOI: $10.5171 / 2021.707843$

Research Article

\title{
SMEs in Failed Transition Towards Industry 4.0: A case study of a Czech SME
}

\author{
Marcel Rolf Pfeifer \\ Faculty of Business and Management \\ Brno University of Technology, Kolejní 2906/4, 61200 Brno, Czech Republic, \\ Email: pfeifer@vutbr.cz
}

Received date: 4 March 2021; Accepted date:5 July 2021; Published date: 28 October 2021

Academic Editor: Radosław Miśkiewicz

Copyright (c) 2021. Marcel Rolf Pfeifer. Distributed under Creative Commons Attribution 4.0 International CC-BY 4.0

\begin{abstract}
With upcoming new smart technologies, Small and Medium-sized Enterprises (SMEs) have to deal with the implementation of industry 4.0 and smart principles. Being known for their constraints in human, technical, and financial resources, SMEs may struggle in the transition phase during introducing industry 4.0. A case study from the Czech Republic should shed some light on the opportunities and issues of the introduction of industry 4.0 in an SME in practice. With an initial plan to target the introduction of industry 4.0 in six steps, the company and its transition project had been overseen in the course of four years, in which the company was able to achieve the first steps of the project successfully. However, the core of industry 4.0 principles was overthrown due to missing expertise and resources. Sum-up meetings and expert interviews in the company created the picture that the company and its workers did not fully understand the core of industry 4.0 due to this missing expertise. This company overrated its abilities, and as a result, the company confirmed that the self-set initial project was out of its research and out of its interest. This paper suggests that SMEs do not only struggle with the resources, but also with the expertise and the management support in terms of difficulties concerning new technologies. With the threat to go into a failed transition, SMEs may need to acquire external expertise in order to be prepared for the upcoming challenges.
\end{abstract}

Keywords: Industry 4.0, Case study, Czech Republic, Transition, Failure, Smart

\section{Introduction}

As economy transits towards industry 4.0 , the expected changes will have impacts on companies of all sizes and branches. Small and Medium-sized Enterprises (SMEs) aggregated are the main industrial contributors in many countries and economies (Li et al., 2016). As SMEs were identified as the least benefiting from

Cite this Article as: Marcel Rolf Pfeifer (2021)," SMEs in Failed Transition Towards Industry 4.0: A case study of a Czech SME", Journal of Innovation \& Business Best Practice, Vol. 2021 (2021), Article ID 707843, DOI: $10.5171 / 2021.707843$ 
supply chains (Vaaland and Heide, 2007), these companies struggle to keep up with the rising requirements. However, industry 4.0 should have the potential to open markets and opportunities for SMEs (Kotler, Kartajaya and Setiawan, 2016) by decreasing transaction costs and applying new technologies (Catalini and Gans, 2020).

While SMEs are estimated to be able to reduce transaction costs and adapt to new technologies fast, research has shown that SMEs usually react in the opposite way. SMEs are hesitant to introduce new technologies (Vaaland and Heide, 2007) due to the cost involved representing huge investments compared to the overall revenues of the companies (Sevinc, Gür and Eren, 2018). Studies show that the least expensive technologies are those that SMEs tend to stick to (Moeuf et al., 2017). The room for error is smaller compared to the possibilities that Large Enterprises (LEs) have. Beside finances, studies also identified skills and expertise to be missing in SMEs (Moeuf et al., 2016), as many systems proved out to be too costly and too complex (Cullinan, Sutton and Arnold, 2010).

SMEs are struggling to keep up with the pace of the competition, as suggested by studies from the 1990 s and the 2000s. The implementation of the Toyota Production System (TPS) (Moeuf et al., 2016) and of MRP (McGarrie, 1998; Petroni, 2002) already represented sharp hurdles for these companies. While the mentioned studies are of older date already, it must be said that recent studies also confirmed the hesitant behavior of SMEs to implement new technologies. Small start-ups are known to be highly flexible, targeting shares in the market, existing SMEs struggle to maintain their position by hesitating to implement innovations.

Research on the investment of SMEs into new technologies show that it is still a pending topic today. Also, in the case of industry 4.0, SMEs are hesitant to implement it due to the big investment and the possible related risk for the company (Valdez et al., 2015). Research from Finland has shown that the important key to the success of internationalized SMEs lies in targeting a niche or in following key customers abroad. Research has also shown that fast internationalization allowed for high growth rates, while gradual internationalization showed only moderate improvements (Kuivalainen, Saarenketo and Puumalainen, 2012). On the other hand, it was also found out that highly-uncertain environments provide a framework for successful start-ups, including high growth rates and a future market-leadership (Deeds, 2001).

Present SMEs seem to search for partnership and expertise to conquer the challenges of industry 4.0 (Türkes et al., 2019), once they understand the benefits of the implementation (Baritto et al., 2020). With financial and technical resources on a low level (Mittal et al., 2018), research showed that even maturity models for industry 4.0 may need an additional level, as an entry level for SMEs (Mittal et al., 2018). While research done at a university laboratory in Austria identified the crucial steps and their priorities during the implementation (Karre et al., 2017), SMEs might not even be in the position to work off the steps required, with industry 4.0 being sensitive to the qualifications and skills of the companies (Benešova and Tupa, 2017).

Studies assume that the benefits from introducing industry 4.0 frameworks are far greater than their costs (Ghobakhloo, 2018). By developing Information and Communication Technologies (ICT), SMEs shall make their first step to target industry 4.0 , being able to vertically integrate suppliers and customers (Kolla, Minufekr and Plapper, 2019). While industry 4.0 is expected to change the rules of competition (Kagermann, 2015), it is the opportunity for SMEs to catch up with the big players. Using the Internet of Things (IoT) allows companies to synchronize analogue and digital processes (Huber and Kaiser, 2015) to raise the standard of their own production.

SMEs' challenges and opportunities from the fourth industrial revolution are manifold. Previous research suggests that 
SMEs are facing other challenges than LEs, making it difficult for them to adapt to new technologies. This case study aims to have a look on one SME from the Czech Republic, analyzing its concrete steps to implement industry 4.0 .

\section{Literature Review}

Studies showed that SMEs are known to be weak players in supply chains (Vaaland and Heide, 2007), while industry 4.0 promises high potentials for those companies with less than 250 employees (definition by the European Commission (2003)). Comparing the characteristics of SMEs to large Multinational Enterprises (MNEs), Mittal et al. (2018) found seventeen features concerning differences in resources and skills.

SMEs are, by the number of enterprises, the major group in many economies (Li et al., 2016). In Germany, the percentage is as high as $99.6 \%$ (Bär, Herbert-Hansen and Khalid, 2018). Thus, it is of great importance for these economies not to lose these companies during the economic transition towards industry 4.0. Research also showed that SMEs require particular training to be able to exploit the benefits from industry 4.0 (Faller and Feldmüller, 2015). A second study from Germany published in the same year found that German SMEs were aware of the need to transit towards industry 4.0; however, a majority of companies was only showing a small movement (Sommer, 2015) to include IoT into their organization (Müller, 2019).

A research from Norway on SMEs concluded that strategic planning and IT management are not significantly required for e-business. However, IT-business process integration, and systems- and infrastructure-associated features should be significantly crucial requirements (Eikebrokk and Olsen, 2007). IT is an important tool, as industry 4.0 relies on cyber-physical processes and networks (Köroglu, 2015). The further evolution in IoT will also require companies not to come to a standstill, but rather to foster a stable environment for evolution (Abdel Basset et al., 2019). All new technologies need to be integrated into the organization (Ghobakhloo and Fathi, 2019).

Research suggests that for smaller companies, the start for digitization should be made gradually, suggesting to develop lean-digitized manufacturing systems (Ghobakhloo and Fathi, 2019). Another approach suggested by German researchers was to cooperate with other, more knowledgeable companies. The study found out that SMEs were not yet ready for cooperation, as they did not understand their roles and the business model behind them (Müller, R. et al., 2017). Moreover, while companies rated IoT to be of low complexity, they also rated it to be of low importance for their business and economic welfare (Masood and Sonntag, 2020). There is a theoretical belief that with the change in the manufacturing framework, the organizational framework has to change as well (Hirsch Kreinsen, 2016).

An Indian research suggested that SMEs were under pressure and motivation from their customers to change (Kumar, Somgj and Dwivedi, 2020). This spreading effect was also waited for in Denmark, where a survey found that the diminishing barriers for SMEs to introduce industry 4.0 would not directly lead to an implementation of it (Stentoft et al., 2019). Further research conducted in Italy found that SMEs with a lean organization were better able to introduce industry 4.0 (Cimini et al., 2020), while in 2019 , about $20 \%$ of all mediumsized companies should have already taken steps towards its introduction (Mediobanca-Unioncamere, 2019). Such companies were able to enforce automation while finding difficulties in higher adequate personnel (Garbellano and Rosário Da Veiga, 2019).

An Indian study suggested entrepreneurialoriented SMEs to be the fastest in adapting to new technologies (Sahi, Gupta and Cheng, 2020). In order to provide a simplified introduction to industry 4.0 for SMEs, the framework should allow for 
partial integration and extension, making use of the internal resources (Dassisti et al., 2019). However, companies were still in the phase of finding strategic approaches for the introduction, rather than doing hasty steps (Pirola, Cimini and Pinto, 2019). In order to support SMEs, governments and organizations, e.g. in Taiwan, decided to establish financial incentives to give and develop new motivations to invest in industry 4.0 (Lin, Shyu and Ding, 2017). This crucially requires that SMEs have to be prepared to receive the support (Santos, CharruaSantos and Lima, 2018).

Since many SMEs are working as part of a supply chain, it is important for those companies to stick to their suppliers and customers. To make use of the supply chain, SMEs need to internalize the trickledown effects (Smit et al., 2016). However, Piccarozzi et al. claim that the benefits of industry 4.0 were overestimated in the researches done, as is common for new technologies (Piccarozzi, Aquilani and Gatti, 2018). While some companies in Italy implemented industry 4.0 in a rush "learning by doing", authors suggest that SMEs should have a proper plan on the implementation, from the technical, financial, and production point of view (Majeed and Rupasinghe, 2017). Industry 4.0 is understood as a development of a new competitive framework through horizontal integration (Brettel et al., 2014).

Applying a stage model, research found four levels of implementation of industry 4.0 for SMEs, beginning as Craft manufacturers, to a preliminary stage of scanning the market, to Industry 4.0 users for parts of their work, and finally to Fullscale adopters in the whole company (Müller, Buliga and Voigt, 2018). This also corresponds to findings of a three-stage model that begins with level 1 of the aforementioned four levels (Ganzarain and Errasti, 2016). For companies to overcome the first step, industry 4.0 requires higher flexibility and higher customization (Torn and Vaneker, 2019). The striving for implementing this framework itself incorporates a change in the organizational structure of the company as well (Shin, 2017).

It should be taken into account that several researches touched the issue of industry 4.0-maturity, implementation and business models of industry 4.0 and for SMEs as well (Theorin et al., 2017). While different companies have a different approach and different names (Nouvelle France Industrielle, Fabbrica Intelligente, Made in China 2025) for their industry 4.0initiatives, further research led to the same research questions, issues and open topics (Trotta and Garengo, 2018). Hence, SMEs all around the world are struggling to incorporate the required principles and technologies, with their information systems and technologies being fragmented and only rudimentary integrated (Ingaldi and Ulewicz, 2019). The missing integrative culture may present a hurdle for those enterprises that do not have technical expertise.

SMEs have a limited scope of products and production possibilities (Ingaldi and Ulewicz, 2019) and with limited space for error. A potential way to face that challenge is the industry 4.0 laboratory, called the Learning Factory, in which research is conducted, to acquire additional understanding and knowledge (Erol et al., 2016). To acquire knowledge, learning factories and the relationship of manufacturing and education provide frameworks for the introduction of principles, taking into account the missing expertise and human skills in SMEs (Elbestawi et al., 2018; Paravizo et al., 2018). However, transferring ideas and expertise from a laboratory environment to manufacturing companies is still a challenge (Prinz, Kreimeier and Kuhlenkötter, 2017). New approaches that are tightly-related to learning factories target gamification and game-based learning (Paravizo et al., 2018).

While supply chains are usually understood as a cooperation of differentlysized companies, research suggested that with industry 4.0, supply chains of only small-sized companies should also be possible (Chen, 2019). These companies 
showed lack of skills, such as methodology and social competencies (Quattrociocchi et al., 2018). Research on two SMEs from Sweden showed that these companies were working in a digitized environment but did not make use of this digitization in production (Li, Fast-Berglund and Paulin, 2019). Overcoming this step to introduce industry 4.0 in the company, should benefit departments and processes likewise (Müller, J. et al., 2017). Studies conducted in 2018 suggested that particularly manufacturing processes would be suitable for automation and industry 4.0 (Buer, Strandhagen and Chan, 2018; Müller, Buliga and Voigt, 2018).

With SMEs checking, approving, and processing drawings manually, a smart shop floor application may change the nature of the company's production from manual to digitized (Müller, R. et al., 2017). However, several case studies have shown that even the decision for more digitalized production has not led to the required results. This is due to the fact that operator skills make intelligent operators for smart companies (Marešova et al., 2018). Companies and industries that were known for higher quantities of unskilled workforce were also getting into the focus of research (Rahman et al., 2020). However, the question about balancing environmental, social, and technical impacts was still unanswered (Nwaiwu et al., 2020).

Research published in 2019 showed that beside the skills of its workforce, there is also a question about supporting industry 4.0 by the management (Agostini and Nosella, 2019). Concerning the IT security, SMEs are lacking the possibilities and skills to react to cyber-attacks (Radanliev et al., 2019). As such, SMEs are considered to be a threat for themselves and also for other companies in linked and integrated supply chains. The program Made-in-China 2025, governed by the Chinese state, educated thousands of young graduates for the development of these technologies (Li, 2018). Fostering a culture of collaborative behavior and making use of spill-over effects from suppliers and customers is not yet present in these companies (Camarinha-Matos, Fornasiero and
Afsarmanesh, 2017). Tools invented for LEs may need to be downsized in order to fit SMEs. Approaches were already made in research (Brozzi et al., 2018).

However, a study from Norway came to the conclusion that SMEs did not consider information systems to be a vital part of their daily business (Vaaland and Heide, 2007). As industry 4.0 technologies are also applicable to work with data of machines and production devices (Hu et al., 2019), the outlook to implement IoT into the company makes it feasible to think about the security of data and the whole system. Hence, skilled personnel is not only required on the shop floor, but it will also be needed in later stages in the IT security department (Keenan and Alice, 2017; Ye et al., 2018). As found out for other areas, the IT security in SMEs awaits a cost increase once implementing industry 4.0 (Wong et al., 2020).

Beside the cost, it is anticipated that the management functions also transform. The impact of industry 4.0 on the management seemed to frighten the middle management in such a way, that it ought to take a defensive and rejecting response. Beside the disadvantages compared with MNEs, SMEs were assumed to have a less complex and bureaucratic ballast, and fewer obstacles in technical and cooperation topics (Horvath and Szabó, 2019). Industry 4.0 is assumed to change many, if not all, existing rules and habits (Porter and Heppelmann, 2014). This inhibits not only challenges, but also new opportunities. Companies and their managers have to focus on being ready to introduce industry 4.0 whenever required (Kiel et al., 2017; Nagy et al., 2018).

SMEs were expected by the research to be in a weak position in supply chains and in the availability level of financial, technical, and manufacturing resources. On the other hand, SMEs were seen as being less complex and having less bureaucratic ballast, making them flexible. The IoT should give them the opportunity to catch up and to make use of channels and resources that are far hidden for them. 
While SMEs have to decide and outweigh whether and when to invest into industry 4.0 , this decision involves costs and benefits. Initiatives from governments all over the world have the target to facilitate the development of SMEs, trying to give incentives to invest into smart technologies and industry 4.0. However, the decision is made by companies with wide implications, making it invisible for managers and researchers.

\section{Methodology}

This research paper aims to have a look on the implementation of an industry 4.0 concept in an SME in the Czech Republic. For the definition of the concept and the measures taken, the SME itself defined the concept and its goals. The concept was introduced with the financial constraints faced by SMEs. In order to evaluate the success of the implementation, it was decided to apply a questionnaire asking for the perception of company internals. The perception of company internals was measured based on a Likert scale and was evaluated based on the average values of the perceptions. The perceptions of the personnel were asked for after the initial investment in the industry 4.0 project was understood as finished. The following case study presents an understanding on the lessons learned, as well as on the basic conception taken in order to achieve a successful industry 4.0 project for SMEs. The initial plan of implementing the concept should be enlarged by including the items that the personnel of the company evaluated as missing. As for SMEs, the challenges inhibit constraints of knowledge, technology, and human and financial resources.

\section{Object of Study}

The company under study belonged to the group of SMEs in the Czech Republic. In the beginning of the project, the company employed 55 employees of all levels. Due to the economic boom in the Czech Republic in the following years, the headcount of the company during its evaluation was 68 employees. According to the classification given by the EU, the company transited from a small to a medium-sized enterprise in the recent years (European Commission, 2003) during its first approach of implementing industry 4.0. The company was specialized in the field of aluminum and metal machining.

The company manufacturing employed a total of 32 workers, of which there were one manager responsible for operations, one secretary, and two shifts with one shift leader and fourteen workers. Production was done based on customer drawings and customer processes. For the machining, the company disposed of three and five axis CNC machines. These machines were not linked to the company's tailor-made information system. The shop floor was still managed with accompanying papers rather than with technology, such as barcodes or RFID. The accompanying welding shop was working exclusively with manual welding, allowing for manual welding errors which further influenced factors in the welding process.

\section{Research}

This paper covers the initial findings of the case study. It was designed to describe the first steps of an SME in the Czech Republic in the transition towards industry 4.0. The steps and the results are presented in table 2 and table 3. Without going into deeper details, the evaluation of the first transition project of the company was conducted as a self-evaluation. The self-evaluation was given as plain text by the operations manager giving the status of the project. A research questionnaire was applied in order to evaluate the individual perceptions of the company's employees and managers on the different stages of the transition process. In order to do so, the different stages were defined in the concept of the project. While including already gathered additional information, in the first step, the company assesses the perception of the company's employees in a questionnaire after the project ends. 


\section{Research Questionnaire}

While the research questionnaire only asked for the perception of employees of the company on each individual phase, there is only one factor contributing to the perception index. This factor was derived as the average value of the given perceptions for each individual stage, which was taken as a measure of success. Hence, each employee of the company, regardless of his/her profession, specialization, and standing, had to fill in and hand in the questionnaire. The rating was done based on a Likert scale that allowed a rating for each particular stage with the minimum scale value of 1 and a maximum scale value of 5 . It was anticipated that the mean value of the interval was the awaited value for a neutral position. Significantly lower perception indices would show a negative rating of the stage, while significantly higher values showed a positive rating.

A second part of the questionnaire conducted focused on the issues experienced by the company during the project, in particular the issues that brought the whole project to an end. In order to reduce the selection, in the first round, all company employees were allowed to give a suggestion of an issue on their own. The suggestions were then presented to all participants. In the second round, the employees had to give their ratings for their perceptions of the most significant issue. Each employee had three anonymous votes. These votes were counted at the end of the vote and the absolute number of the votes was counted for each issue. The four issues with the highest number of votes are shown in table 3 and are seen as the most significant issues the company identified in its approach towards industry 4.0 after the first analysis.

\section{Statistical Analysis}

For the first part of the analysis, the results from the Likert scale were analyzed according to their statistical significance. With the sample means and Standard Deviations (SD), a two-sided Student's Ttest was applied. This T-test was designed as a one sample T-test with a significance level of $p<0.05$. The anticipated neutral value for each stage was set to 3 , being the mean value of the Likert scale assessment possibilities.

For a normal distribution of the sample, a Kolmogorov-Smirnov test was applied with a significance level of $p<0.05$. This means that the sample would be shifted if the following $\mathrm{T}$-test had to reject the $\mathrm{H}_{0}$ hypothesis. This $\mathrm{H}_{0}$ hypothesis assumed no shift in the mean value. Based on the mean values and the corresponding standard deviations, the T-test was conducted for the perception given by the employees on all five stages.

\section{Concept}

The company decided to use a concept of gradual introduction and implementation of the given items. The conceptual framework was developed by the company with support from graduate students from a Czech university. Due to the constraints faced by the company and the low level of interconnectivity available, the company focused on the basic steps of the introduction. With financial support from the European funds, the company decided to take a step towards industry 4.0. While MNE topics might be more complex, the mentioned SME focused on the basic connection of the company's information system with the shop floor (table 1). The time frame of the implementation was set to four years. 
Table 1: Items of introduction of industry 4.0 during case study (own proceedings)

\begin{tabular}{|c|l|l|}
\hline$\#$ & Item & Description \\
\hline $\mathbf{1}$ & Robot welding cell & $\begin{array}{l}\text { Installation of robot welding cell } \\
\text { Operator training } \\
\text { Maintenance training }\end{array}$ \\
\hline $\mathbf{2}$ & $\begin{array}{l}\text { Implementation of Advanced } \\
\text { Planning Systems (APS) }\end{array}$ & $\begin{array}{l}\text { No manual planning } \\
\text { Planning based on computer } \\
\text { algorithm }\end{array}$ \\
\hline $\mathbf{3}$ & Enlargement of ERP system & $\begin{array}{l}\text { ERP system including APS, RFID } \\
\text { reading modules, and } \\
\text { automatic part manipulation }\end{array}$ \\
\hline $\mathbf{4}$ & RFID reading & $\begin{array}{l}\text { Introduction of RFID reader } \\
\text { Labelling \& re-labelling }\end{array}$ \\
\hline $\mathbf{5}$ & $\begin{array}{l}\text { Automatic part manipulation - } \\
\text { intercompany }\end{array}$ & $\begin{array}{l}\text { Manipulation devices (e.g. belts) } \\
\text { that bring parts from one station } \\
\text { to another based on ERP data }\end{array}$ \\
\hline $\mathbf{6}$ & $\begin{array}{l}\text { Supply chain data flow } \\
\text { connectivity }\end{array}$ & $\begin{array}{l}\text { Introduce EDI for data flow in the } \\
\text { ERP system }\end{array}$ \\
\hline
\end{tabular}

The company focused on a gradual implementation of the items, beginning with the tangible part of them. In a first step, the robot welding cell should be introduced in order to replace manual welding by an automated welding process. Awaiting a boost in availability and productivity, this robot welding cell should also be able to store the welding parameter set for different products by direct exchange with the company's database. The implementation into the company's database should be done in a third phase with the enlargement of the ERP system. Prior to that, an Advanced Planning System (APS) should be implemented, being able to operatively plan orders, maintenance, and further blocks. The data from the APS had also to be linked with the ERP system.

With the included APS and welding cell data, the company targeted installing automatic code readers that would automatically log in and log out a certain order or a certain machine status. Further, it should be used to log in and log out components in the warehouse. In a further step, the intra-operational logistics should be automatized in order to allow for an automated flow of goods and products in the plant. In a last step, the company planned to connect its systems to a first supply chain, exchanging data directly through an Electronic Data Interface (EDI).

\section{Results}

The results were taken after a pre-set period of four years. It was planned to have all activities implemented and working after this time period. A first observation made after these four years was that the company was not able to implement all of its goals during the four-year period. The company was able to complete points 1 to 4 within 45 months. Activity 5 and 6 had not been implemented by the time of the evaluation. Taking into account the revised plans of the company, it was doubtful whether activity 5 and 6 were to be realized in the nearer future. The strategic planning of the company changed its priorities in these four years that it did not see further benefits in the pending activities.

Another outcome of the study, beside the mapped goals, was the perception of the employees in production. This perception was rated on a Likert scale with a minimum value of 1 and a maximum value of 5 . This was to be an initial measure on how successful the implementation of industry 4.0 principles was for the employees of the 
company. As the targets of the company had not been met, the employees, however, rated the transition mostly in a positive manner. For activity 4, the company decided to change its targets by replacing RFID readers with barcode readers. Instead of RFID, information is provided on an information tag as a printed label (table 2).

Table 2: Results of implementation goals in the case study (own proceedings)

\begin{tabular}{|c|c|c|c|c|}
\hline \# & Item & Actual status & $\begin{array}{l}\text { Perception } \\
\text { index }\end{array}$ & $\begin{array}{l}\text { T-test value / } \\
\text { T-test value } \\
\text { crit. }\end{array}$ \\
\hline 1 & $\begin{array}{l}\text { Robot welding } \\
\text { cell }\end{array}$ & $\begin{array}{l}\text { Finished, } \\
\text { completed } 20 \% \\
\text { over budget } \\
35 \% \text { idle }\end{array}$ & 4.2 & $2.00<7.31$ \\
\hline 2 & $\begin{array}{l}\text { Implementati } \\
\text { on of } \\
\text { Advanced } \\
\text { Planning } \\
\text { Systems (APS) } \\
\end{array}$ & $\begin{array}{l}\text { APS system } \\
\text { introduced } \\
15 \quad \text { months } \\
\text { delay }\end{array}$ & 3.7 & $2.00<4.07$ \\
\hline 3 & $\begin{array}{l}\text { Enlargement } \\
\text { of ERP system }\end{array}$ & $\begin{array}{l}\text { ERP system } \\
\text { welding cell and } \\
\text { APS data } \\
10 \text { months } \\
\text { delay }\end{array}$ & 4.4 & $2.00<10.51$ \\
\hline 4 & RFID reading & $\begin{array}{l}\text { Re-planned } \\
\text { with barcode } \\
\text { readers } \\
30 \% \text { cost } \\
\text { savings }\end{array}$ & 4.2 & $2.00<6.64$ \\
\hline 5 & $\begin{array}{l}\text { Automatic } \\
\text { part } \\
\text { manipulation - } \\
\text { intercompany }\end{array}$ & On hold & 2.3 & $2.00<|-3.31|$ \\
\hline 6 & $\begin{array}{lr}\text { Supply } & \text { chain } \\
\text { data flow } \\
\text { connectivity }\end{array}$ & On hold & 1.5 & $2.00<|-9.50|$ \\
\hline
\end{tabular}

As shown in table 2, Student's T-test values show a significant shift of the normal distribution of the perception for all six phases. While the first four stages received a significantly positive evaluation by the company employees, the last two stages received a significantly negative evaluation. The deviation was assessed relatively to a normal distribution with the expected value being the mean value of the Likert scale equaling 3 . On a significance level of $p$ $<0.05$, the $\mathrm{H}_{0}$ hypothesis had to be rejected suggesting that the employees appreciated the first four stages, thinking that the company is not yet capable of going into these areas.

In addition to the perception on the different items, the questionnaire applied also asked the employees about their biggest issues experienced during the project of implementation. Each employee was asked to provide three issues. Table 3 lists the four most-frequently obtained answers. 
Table 3: Biggest issue list (own proceedings)

\begin{tabular}{|l|l|l|}
\hline$\#$ & Issue & Quantity \\
\hline 1 & Time frame not real & 24 \\
\hline 2 & $\begin{array}{l}\text { Accompanying requirements } \\
\text { neglected during planning }\end{array}$ & 20 \\
\hline 3 & $\begin{array}{l}\text { Missing expertise caused } \\
\text { misunderstanding of internal } \\
\text { skills }\end{array}$ & $\begin{array}{l}\text { Essence of industry 4.0 not } \\
\text { implemented }\end{array}$ \\
\hline 4
\end{tabular}

\section{Discussion}

The company was able to realize its first three self-set targets within the given time period of four years. However, the fourth target had to be re-defined during the stage of detailed planning. Instead of RFID sensors for full traceability of parts and boxes in the manufacturing, the company decided to use barcode labels. Due to the required financial resources and due to the manageable size of the company, the management decided to re-evaluate the priority of RFID tags. The upcoming activities, activity 5 and activity 6 , were not conducted in the pre-set time frame. Moreover, the company decided to put these activities on hold as the requirement of additional skills and resources, due to the uncertainty, was a risk the management did not want to take. Also, in the nearer future, it may not be anticipated that these activities would be conducted. The reason given by the company management was the lack of experience of the company and the moderate level of pressure from customers to introduce the EDIs. Hence, the company considered the implementation phase of industry 4.0 as finished.

The company conducted the first steps with financial support from the European funds. However, once the company reached the activities related to technologies with the industry 4.0 concept, the company management decided to end the project skipping these activities. This is due to the resource-intensive implementation, requiring technology, finances, and human resources and skills likewise. Therefore, the project of industry 4.0-implementation ended half-way through. The company management thought the next activities to be above the current level of the company.

As shown by the evaluation of the ending questionnaire, the company underestimated the challenges of the implementation of new technologies. Being used to work at manual workplaces, the company already faced additional costs in the robot welding station realization because the required training exceeded the planned time frame. This was also shown in the second phase where the APS implementation faced a delay of more than one year. Even the small size of the company was not able to facilitate the customization of the APS system and the linking with the company's tailor-made ERP system.

Together with the insufficiently-planned training and set-up requirements, the company also overestimated its internal skills. This was one of the findings from the final survey. While the core industry 4.0stages were not realized, this SME did struggle with the basic technologies, being able to implement them at the end. The reevaluation of the situation led to the understanding that the own skills and the own expertise and knowledge were not sufficient to go for a further implementation. As a result, the company's robot welding cell is to a high percentage idle. While advanced technologies may 
bring higher productivity, the SME is not able to benefit from it.

The given company was just in the transition from being small to mediumsized one. Compared to LEs, SMEs, though belonging to supply chains of the automotive industry, disposed of insufficient skills and a far different structure. Despite a lower complexity, the SME was not able to implement its targets. Considering industry-4.0 implementation as a strategic project, the company decided to cancel part of the project, due to low pressure from its customers. While the SME assumed to be able to provide further services for its customers, these customers seemed not to require those services currently. The strategic project did not even target the customer, but seemed to be driven by the awaited potentials.

This case study only presented one company that tried to build its own way and interpretation of industry 4.0. Taking into account the understanding from publications all around the world, the understanding of industry 4.0 is much wider than what this company defined. The trend towards cyber-physical systems duplicates the real flows of materials and goods with an information flow. The flow of material and information, in parallel, allows for fast reactions, full information, and full traceability. The company in the case study did not go that far, stopping before reaching industry 4.0. Further studies have to clarify whether this is a structural issue of SMEs or it is an issue of a few companies.

Also, the perception of the employees in the company made clear that that the company underestimated the challenges of industry 4.0 and its smart principles. Moreover, they claimed that the company did not implement the core of industry 4.0, corresponding with the findings of this research. Additionally, $80 \%$ of the employees in production found that the time frame was not real and additional requirements were forgotten. The missing knowledge as well as the overestimation of the internal skills led to ending the project after activity 4. Employees of the company also identified the issue regarding the company culture and the company structure, as well as the lack of skills, and therefore, the failure of this project was identified as coming from within the company.

\section{Conclusion}

Studies showed that SMEs are known to be weak players in supply chains (Vaaland and Heide, 2007). Unlike start-ups, SMEs have to work in an already established framework filling the place they acquired in their history. As such, these companies have a different understanding of investment and its returns. The pressure on financial resources and the given time frame of visionary projects differ in established SMEs. The Tesla story shows that a start-up and its investors are able to cover losses over a longer period of time. For SMEs, it is doubtful that such projects would be realized. SMEs already achieved knowledge and expertise in a specific field.

In order to suite the requirements of supply chains, this SME would not be able to provide the services linked to industry 4.0. The understanding of what belongs to industry 4.0 principles differs widely. The level of implementation of this case study remained low, as the company did not even succeed in implementing what was seen as state of the art at that time. While the company aborted the application of further integrated services, such as IoT, not succeeding in its path to implement industry 4.0, the company did not identify all potential features and issues. Topics, such as IT and data security, were not targeted.

As a further outlook, it must be said that already established SMEs may have difficulties in transition towards industry 4.0. While this was only one case study from the Czech Republic, it showed the misunderstanding of industry 4.0, technology-wise and culture-wise. This may also explain why the management aborted the further ongoing of the project, trying to reduce costs. Customer-focus had 
never been a criterion for the project. Assuming that cyber-physical networks facilitate the integration within the company and also in supply chains, the benefits of coexistence lie in the faster data transmission and the higher volume of data that may be processed. Not making use of this data, as in the given case, is contradictory to the full traceability of production.

Future research needs to target the question, whether this case was a unique case of overestimating the company's own strengths, or it is a fundamental issue of SMEs to transit towards industry 4.0. While SMEs are known to be the weakest members of supply chains, new topics that require additional financial and technological resources represent obstacles for them. IT security was identified as an issue of new IoT technologies inhibiting a high portion of risks (Keenan and Alice, 2017; Khan and Estay, 2015) or the whole supply chain. The exchange of data should be exclusively available for partners in the supply chain, while outsiders should not have any access.

While these requirements are a vital part of industry 4.0 and smart companies, today's SMEs may struggle to provide basic services. For supply chains and their security, the authors suggested that it may be suitable to provide a supply chain governor responsible for the compliance of all supply chain risks. In case of a systematic failure of SMEs' company culture in further cases, management members have to think about new ways on how to make SMEs mentally ready for the transition to industry 4.0. Being vital to stay on the market in the future, governments promoting industry 4.0 have to also think about a way to facilitate and support these companies. In order to prevent SMEs from what was shown in this case study, governments should have an interest in a successful transition.

\section{Acknowledgment}

Special thanks go to the managers and workers of the company of the case study who requested for anonymity.

\section{References}

- Abdel-Basset, M., Nabeeh, N., ElGhareeb, H., \& Aboelfetouh, A. (2019), 'Utilising neutrosophic theory to solve transition difficulties of IoT-based enterprises,' Enterprise Information Systems, 14(9-10), 1304-1324.

- Agostini, L., \& Nosella, A. (2019), 'The adoption of Industry 4.0 technologies in SMEs: results of an international study,' Management Decision.

- Bär, K., Herbert-Hansen, Z., \& Khalid, W. (2018), 'Considering Industry 4.0 aspects in the supply chain for an SME,' Production Engineering, 12(6), 747758.

- Baritto, M., Billal, M., Nasim, S., Sultana, R., Arani, M., \& Qureshi, A. (2020), 'Supporting Tool for The Transition of Existing Small and Medium Enterprises Towards Industry 4.0,' International Conference on Data Analytics for Business and Industry.

- Benešová, A., \& Tupa, J. (2017), 'Requirements for education and qualification of people in Industry 4.0,' Procedia Manufacturing, 11, 21952202.

- $\quad$ Brettel, M., Friederichsen, N., Keller, M., \& Rosenberg, M. (2014), 'How virtualization, decentralization and network building change the manufacturing landscape: An Industry 4.0 Perspective,' International journal of mechanical, industrial science and engineering, 8(1), 37-44.

- Brozzi, R., D'Amico, R., Pasetti Monizza, G., Marcher, C., Riedl, M., \& Matt, D. (2018), 'Design of Self-assessment Tools to Measure Industry 4.0 Readiness. A Methodological Approach for Craftsmanship SMEs', Product Lifecycle Management to Support Industry 4.0. PLM 2018. IFIP Advances in Information and Communication Technology, vol 540, Chiabert P., Bouras A., Noël F., Ríos J. (eds), Springer, Cham, 566-578.

- $\quad$ Buer, S.V., Strandhagen, J., \& Chan, F. (2018), The link between Industry 4.0 and lean manufacturing: mapping 
current research and establishing a research agenda. International Journal of Production Research, 56(8), 29242940.

- Camarinha-Matos, L., Fornasiero, R., \& Afsarmanesh, H. (2017), 'Collaborative Networks as a Core Enabler of Industry $4.0^{\prime}$, IFIP Advances in Information and Communication Technology, vol 506, Camarinha-Matos L., Afsarmanesh H., Fornasiero R. (eds.), Springer, Cham, 3-17.

- Catalini, C., \& Gans, J. (2020), 'Some simple economics of the blockchain,' Communications of the ACM 63(7) (2020), 80-90.

- Chen, C.L. (2019), 'Value Creation by SMEs Participating in Global Value Chains under Industry 4.0 Trend: Case Study of Textile Industry in Taiwan,' Journal of Global Information Technology Management, 22(2), 120145.

- Cimini, C., Boffelli, A., Lagorio, A., Kalchschmidt, M., \& Pinto, R. (2020), 'How do industry 4.0 technologies influence organisational change? An empirical analysis of Italian SMEs,' Journal of Manufacturing Technology Management, ahead-of-print(ahead-ofprint),

- Cullinan, C., Sutton, S., \& Arnold, V. (2010), 'Technology monoculture: ERP systems, techno-process diversity and the threat to the information technology ecosystem,' Advances in Accounting Behavioral Research, 1330.

- Dassisti, M., Giovannini, A., Merla, P., Chimienti, M., \& Panetto, H. (2019), 'An approach to support Industry 4.0 adoption in SMEs using a coremetamodel,' Annual Reviews in Control, 47, 266-274.

- Deeds, D. (2001), 'The role of R\&D intensity, technical development and absorptive capacity in creating entrepreneurial wealth in high technology start-ups,' Journal of Engineering and Technology Management, 18(1), 29-47.

- Eikebrokk, T., \& Olsen, D. (2007), 'An empirical investigation of competency factors affecting e-business success in
European SMEs,' Information \& Management, 44(4), 364-383.

- Elbestawi, M., Centea, D., Singh, I., \& Wanyama, T. (2018), 'SEPT Learning Factory for Industry 4.0 Education and Applied Research,' Procedia Manufacturing, 23, 249 - 254.

- Erol, S., Jäger, A., Hold, P., Ott, K., \& Sihn, W. (2016), 'Tangible Industry 4.0: A Scenario-Based Approach to Learning for the Future of Production,' Procedia CIRP, 54, 13-18.

- European Commission (2003), 'Commission Recommendation of 6 May 2003 concerning the definition of micro, small and medium-sized enterprises,' European Commission. [Online], [Retrieved March 20, 2021],

- https://eur-lex.europa.eu/legalcontent/EN/TXT/?uri=celex\%3A3200 3H0361

- Faller, C., \& Feldmüller, D. (2015), 'Industry 4.0 Learning Factory for regional SMEs,' Procedia CIRP, 32, 8891.

- Ganzarain, J., \& Errasti, N. (2016), 'Three stage maturity model in SME's toward industry 4.0,' Journal of Industrial Engineering and Management, 9(5), 1119.

- Garbellano, S., \& Rosário Da Veiga, M. (2019), 'Dynamic capabilities in Italian leading SMEs adopting industry 4.0,' Measuring Business Excellence, 23(4), 472-483.

- Ghobakhloo, M. (2018), 'The future of manufacturing industry: a strategic roadmap toward Industry 4.0,' Journal of Manufacturing Technology Management, 29(6), 910-936.

- Ghobakhloo, M., \& Fathi, M. (2019), 'Corporate survival in Industry 4.0 era: the enabling role of lean-digitized manufacturing,' Journal of Manufacturing Technology Management, 31(1), 1-30.

- Hirsch-Kreinsen, H. (2016), 'Digitization of industrial work: development paths and prospects,' Journal for Labour Market Research, 49(1), 1-14.

- Horváth, D., \& Szabó, D. (2019), 'Driving forces and barriers of Industry 
4.0: Do multinational and small and medium-sized companies have equal opportunities?,' Technological Forecasting and Social Change, 146, 119-132.

- Hu, J.W., Yeh, L.Y., Liao, S.W., \& Yang, C.S. (2019), 'Autonomous and malware-proof blockchain-based firmware update platform with efficient batch verification for Internet of Things devices,' Computers \& Security, 86, 238-252.

- Huber, D., \& Kaiser, T. (2015), 'Wie das Internet der Dinge neue Geschäftsmodelle ermöglicht,' Praxis der Wirtschaftsinformatik, 52(5), 681689.

- Ingaldi, M., \& Ulewicz, R. (2019), 'Problems with the Implementation of Industry 4.0 in Enterprises from the SME Sector,' Sustainability, 12(1), 217.

- Kagermann, H. (2015), 'Change Through Digitization - Value Creation in the Age of Industry 4.0,' Management of Permanent Change, Albach, J., Meffert, H., Pinkwart, A. and Reichwald, R. (eds.), Springer Gabler, Wiesbaden, 23-45.

- Karre, H., Hammer, M., Kleindienst, M., \& Ramsauer, C. (2017), 'Transition towards an Industry 4.0 State of the LeanLab at Graz University of Technology,' Procedia Manufacturing, 9, 206-213.

- Keenan, T. (2017), 'Alice in blockchains: surprising security pitfalls in PoW and PoS blockchain systems,' 2017 15th Annual Conference on Privacy, Security and Trust (PST), pp. 400-4002.

- Khan, O., \& Estay, D. (2015), 'Supply chain cyber-resilience: Creating an agenda for future research,' Technology Innovation Management Review, 5(4),

- Kiel, D., Müller, J., Arnold, C., \& Voigt, K.I. (2017), 'Sustainable industrial value creation: Benefits and challenges of industry 4.0,' International Journal of Innovation Management, 21(08), 1740015.

- Kolla, S., Minufekr, M., \& Plapper, P. (2019), 'Deriving essential components of lean and industry 4.0 assessment model for manufacturing SMEs', Procedia CIRP, 81, 753-758.

- Köroglu, O. (2015), 'Internet of Things, Sensor Networks and Media,' Proceedings of the Academic Informatics 2015 Conference, Eskisehir, Turkey.

- Kotler, P., Kartajaya, H., \& Setiawan, I. (2016), Marketing 4.0: Moving from traditional to digital, John Wiley \& Sons, New Jersey.

- Kuivalainen, O., Saarenketo, S., \& Puumalainen, K. (2012), 'Start-up patterns of internationalization: A framework and its application in the context of knowledge-intensive SMEs,' European Management Journal, 30(4), 372-385.

- Kumar, R., Singh, R., \& Dwivedi, Y. (2020), 'Application of industry 4.0 technologies in SMEs for ethical and sustainable operations: Analysis of challenges,' Journal of Cleaner Production, 275, 124063.

- Li, D., Fast-Berglund, A., \& Paulin, D. (2019), 'Current and future Industry 4.0 capabilities for information and knowledge sharing,' The International Journal of Advanced Manufacturing Technology, 105(9), 3951-3963.

- Li, L. (2018), 'China - manufacturing locus in 2025: With a comparison of "Made-in-China 2025" and "Industry 4.0",' Technological Forecasting and Social Change, 135, 66-74.

- Li, W., Liu, K., Belitski, M., Ghobadian, A., \& O'Regan, N. (2016), 'e-Leadership through strategic alignment: An empirical study of small-and mediumsized enterprises in the digital age,' Journal of Information Technology, 31(2), 185-206.

- $\quad$ Lin, K., Shyu, J., \& Ding, K. (2017), 'A Cross-Strait Comparison of Innovation Policy under Industry 4.0 and Sustainability Development Transition,' Sustainability, 9(5), 786.

- Majeed, A., \& Rupasinghe, T. (2017), 'Internet of things (IoT) embedded future supply chains for industry 4.0: An assessment from an ERP-based fashion apparel and footwear industry,' International Journal of 
Supply Chain Management, 6(1), 2540.

- Maresova, P., Soukal, I., Svobodova, L., Hedvicakova, M., Javanmardi, E., Selamat, A., \& Krejcar, O. (2018), 'Consequences of Industry 4.0 in Business and Economics,' Economies, 6(3), 46.

- Masood, T., \& Sonntag, P. (2020), 'Industry 4.0: Adoption challenges and benefits for SMEs,' Computers in Industry, 121, 103261.

- McGarrie, B. (1998), 'Case study: production planning and control selection, improvement and implementation,' Logistics Information Management, 11(1), 44-52.

- Mediobanca-Unioncamere (2019), 'Indagine Medie Imprese Italiane 20172018'.

- Mittal, S., Khan, M., Romero, D., \& Wuest, T. (2018), 'A critical review of smart manufacturing \& Industry 4.0 maturity models: Implications for small and medium-sized enterprises (SMEs),' Journal of manufacturing systems, 49, 194-214.

- Moeuf, A., Pellerin, R., Lamouri, S., Tamayo-Giraldo, S., \& Barbaray, R. (2017), 'The industrial management of SMEs in the era of Industry 4.0,' International Journal of Production Research, 56(3), 1118-1136.

- Moeuf, A., Tamayo, S., Lamouri, S., Pellerin, R., \& Lelievre, A. (2016), 'Strengths and weaknesses of small and medium sized enterprises regarding the implementation of lean manufacturing,' IFAC-PapersOnLine, 49(12), 71-76.

- Müller, J. (2019), 'Business model innovation in small- and medium-sized enterprises,' Journal of Manufacturing Technology Management, 30(8), 11271142.

- Müller, J., Buliga, O., \& Voigt, K.I. (2018), 'Fortune favors the prepared: How SMEs approach business model innovations in Industry 4.0,' Technological Forecasting and Social Change, 132, 2 - 17.

- $\quad$ Müller, J., Maier, L., Veile, J., \& Voigt, K.I. (2017), 'Cooperation strategies among SMEs for implementing industry 4.0,'
Digitalization in Supply Chain Management and Logistics: Smart and Digital Solutions for an Industry 4.0 Environment. Proceedings of the Hamburg International Conference of Logistics, Vol. 23 (pp. 301-318),

- Müller, R., Vette, M., Hörauf, L., Speicher, C., \& Burkhard, D. (2017), 'Lean Information and Communication Tool to Connect Shop and Top Floor in Small and Medium-sized Enterprises,' Procedia Manufacturing, 11, 10431052.

- $\quad$ Nagy, J., Oláh, J., Erdei, E., Máté, D., \& Popp, J. (2018), 'The Role and Impact of Industry 4.0 and the Internet of Things on the Business Strategy of the Value Chain-The Case of Hungary,' Sustainability, 10(10), 3491.

- Nwaiwu, F., Duduci, M., Chromjakova, F., \& Funke Otekhile, C.A. (2020), 'Industry 4.0 Concepts within the Czech SME manufacturing sector: An empirical Assessment of critical success Factors,' Business: Theory and Practice, 21(1), 58-70.

- Paravizo, E., Chaim, O., Braatz, D., Muschard, B., \& Rozenfeld, H. (2018), 'Exploring gamification to support manufacturing education on industry 4.0 as an enabler for innovation and sustainability,' Procedia Manufacturing, 21, 438 - 445.

- Petroni, A. (2002), 'Critical factors of MRP implementation in small and medium-sized firms,' International Journal of Operations \& Production Management, 22(3), 329-348.

- Piccarozzi, M., Aquilani, B., \& Gatti, C. (2018), 'Industry 4.0 in Management Studies: A Systematic Literature Review,' Sustainability, 10(10), 3821.

- $\quad$ Pirola, F., Cimini, C., \& Pinto, R. (2019), 'Digital readiness assessment of Italian SMEs: a case-study research,' Journal of Manufacturing Technology Management, 31(5), 1045-1083.

- Porter, M., \& Heppelmann, J. (2014), 'How smart, connected products are transforming competition,' Harvard business review, 92(11), 64-88.

- Prinz, C., Kreimeier, D., \& Kuhlenkötter, B. (2017), 'Implementation of a 
Learning Environment for an Industrie 4.0 Assistance System to Improve the Overall Equipment Effectiveness,' Procedia Manufacturing, 9, 159-166.

- Quattrociocchi, B., Mercuri, F., D’Arcangelo, D., \& Cristini, V. (2018), 'Knowledge management to compete in the digital era: skills evolution of enterprise systems,' Proceedings of the European Conference on Knowledge Management, ECKM, 733-740.

- Radanliev, P., De Roure, D., Nurse, J., Montalvo, R., \& Burnap, P. (2019), 'The Industrial Internet-of-Things in the Industry 4.0 supply chains of small and medium sized enterprises,' University of Oxford, 10.

- $\quad$ Rahman, S., Perry, N., Müller, J., Kim, J., \& Laratte, B. (2020), 'End-of-Life in industry 4.0: Ignored as before?,' Resources, Conservation and Recycling, 154, 104539.

- $\quad$ Sahi, G., Gupta, M., \& Cheng, T. (2020), 'The effects of strategic orientation on operational ambidexterity: A study of Indian SMEs in the industry 4.0 era,' International Journal of Production Economics, 220, 107395.

- Santos, B., Charrua-Santos, F., \& Lima, T. (2018), 'Industry 4.0: an overview,' Proceedings of the World Congress on engineering (pp. 4-6).

- Sevinc, A., Gür, S. \& Eren, T. (2018), 'Analysis of the Difficulties of SMEs in Industry 4.0 Applications by Analytical Hierarchy Process and Analytical Network Process,' Processes, 6(12), 264.

- $\quad$ Shin, D.I. (2017), 'An exploratory study of innovation strategies of the internet of things SMEs in South Korea,' Asia Pacific Journal of Innovation and Entrepreneurship, 11(2), 171-189.

- Smit, J., Kreutzer, S., Moeller, C., \& Carlberg, M. (2016), 'Policy Department A: Economic and Scientific Policy-Industry 4.0,' European Parliament, EU, 1-94.

- Sommer, L. (2015), 'Industrial revolution - industry 4.0: Are German manufacturing SMEs the first victims of this revolution?,' Journal of Industrial Engineering and Management, 8(5).

- $\quad$ Stentoft, J., Jensen, K., Philipsen, K., \& Haug, A. (2019), 'Drivers and barriers for Industry 4.0 readiness and practice: a SME perspective with empirical evidence,' Proceedings of the 52nd Hawaii International Conference on System Sciences.

- Theorin, A., Bengtsson, K., Provost, J., Lieder, M., Johnsson, C., Lundholm, T., \& Lennartson, B. (2017), 'An eventdriven manufacturing information system architecture for Industry 4.0,' International Journal of Production Research, 55(5), 1297-1311.

- Torn, I., \& Vaneker, T. (2019), 'Mass Personalization with Industry 4.0 by SMEs: a concept for collaborative networks,' Procedia Manufacturing, 28, 135-141.

- Trotta, D., \& Garengo, P. (2018), 'Industry 4.0 key research topics: A bibliometric review', 7th International Conference on Industrial Technology and Management. IEEE.

- Türkeș, M., Oncioiu, I., Aslam, H., Marin-Pantelescu, A., Topor, D., \& Capușneanu, S. (2019), 'Drivers and Barriers in Using Industry 4.0: A Perspective of SMEs in Romania,' Processes, 7(3), 153.

- Vaaland, T., \& Heide, M. (2007), 'Can the SME survive the supply chain challenges?,' Supply chain management: an International Journal.

- Valdez, A., Brauner, P., Schaar, A., Holzinger, A., \& Ziefle, M. (2015), 'Reducing Complexity with Simplicity Usability Methods for Industry 4.0.'

- Wong, L.W., Leong, L.Y., Hew, J.J., Tan, G.H., \& Ooi, K.B. (2020), 'Time to seize the digital evolution: Adoption of blockchain in operations and supply chain management among Malaysian SMEs,' International Journal of Information Management, 52, 101997.

- Ye, C., Li, G., Cai, H., Gu, Y., \& Fukuda, A. (2018), 'Analysis of Security in Blockchain: Case Study in 51\%-Attack Detecting,' 5th International Conference on Dependable Systems and Their Applications (DSA), IEEE. 